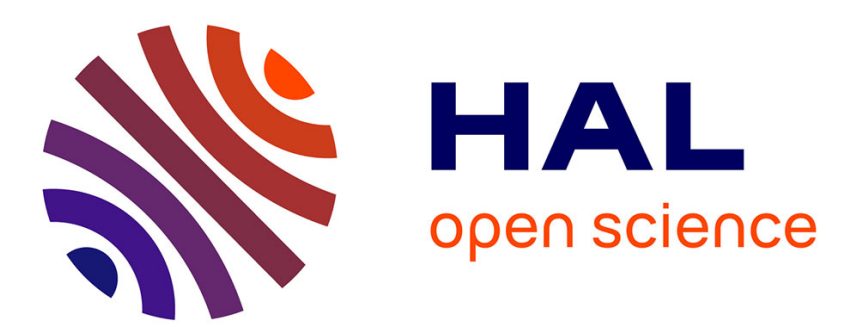

\title{
Monitoring infiltration under a real on-site treatment system of domestic wastewater and evaluation of soil transfer function (Paris Basin, France)
}

Behzad Nasri, Olivier Fouché, David Ramier

\section{> To cite this version:}

Behzad Nasri, Olivier Fouché, David Ramier. Monitoring infiltration under a real on-site treatment system of domestic wastewater and evaluation of soil transfer function (Paris Basin, France). Environmental Earth Sciences, 2014, vol. 73 ( $\mathrm{n}^{\circ}$ 11), pp. 7435-7444. 10.1007/s12665-014-3917-y . hal-01168841

\section{HAL Id: hal-01168841 \\ https://hal.science/hal-01168841}

Submitted on 26 Jun 2015

HAL is a multi-disciplinary open access archive for the deposit and dissemination of scientific research documents, whether they are published or not. The documents may come from teaching and research institutions in France or abroad, or from public or private research centers.
L'archive ouverte pluridisciplinaire HAL, est destinée au dépôt et à la diffusion de documents scientifiques de niveau recherche, publiés ou non, émanant des établissements d'enseignement et de recherche français ou étrangers, des laboratoires publics ou privés. 


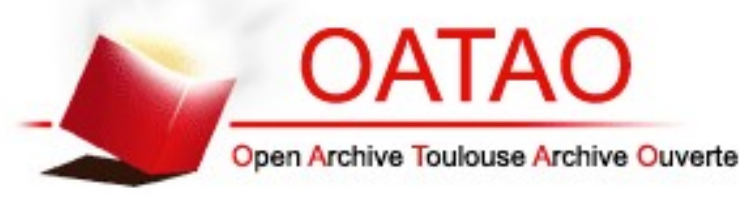

\section{Open Archive TOULOUSE Archive Ouverte (OATAO)}

OATAO is an open access repository that collects the work of Toulouse researchers and makes it freely available over the web where possible.

This is an author-deposited version published in : http://oatao.univ-toulouse.fr/ Eprints ID : 14118

To link to this article : DOI:10.1007/s12665-014-3917-y

URL : http://dx.doi.org/10.1007/s12665-014-3917-y

To cite this version : Nasri, Behzad and Fouché, Olivier and Ramier, David Monitoring infiltration under a real on-site treatment system of domestic wastewater and evaluation of soil transfer function (Paris Basin, France). (2014) Environmental Earth Sciences, vol. 73 (n 11). pp. 7435-7444. ISSN 1866-6280

Any correspondance concerning this service should be sent to the repository administrator: staff-oatao@listes-diff.inp-toulouse.fr 


\title{
Monitoring infiltration under a real on-site treatment system of domestic wastewater and evaluation of soil transfer function (Paris Basin, France)
}

\author{
Behzad Nasri · Olivier Fouché · David Ramier
}

\begin{abstract}
The problem of evacuation of treated domestic wastewater has been investigated through a field study on a real undrained on-site treatment system (UOSTS). This system imposes a special mode of infiltration into the soil which is irregular. To characterize the hydraulic properties of this type of flow, soil texture, organic matter content and in situ saturated hydraulic conductivity (Ks) were measured for each $15 \mathrm{~m}^{2}$ of soil under the bottom of the UOSTS. In addition, the variation of water table and rainfall and the evolution of soil moisture and matrix potential were monitored using the sensors implanted under the system. The mean of the measured Ks is 100 times higher than values deduced from empirical pedotransfer functions based on the soil matrix properties. The measured Ks varies greatly in the $15 \mathrm{~m}^{2}$ area. Moreover, large and variable quantities of stone fragments $(>2 \mathrm{~mm})$ were found in the soil samples. These results suggest that a heterogeneous flow may occur in the stony soil via the macropores which shortcut the soil matrix. Indeed, according to their position, a non-uniform reaction of the sensors to the infiltration of treated wastewater was observed. In addition, two daily periodic peaks of water consumption in the house have been detected by the water
\end{abstract}

B. Nasri $(\bowtie) \cdot$ O. Fouché

LEESU, Ecole des Ponts ParisTech, Universite Paris-Est, 6 et 8 avenue Blaise Pascal, Cité Descartes,

77455 Marne-la-Vallée cedex 2, France

e-mail: behzad.nasri@cnam.fr

\section{B. Nasri · O. Fouché}

Laboratory Géomatique \& Foncier ("GeF"), ESGT,

Conservatoire national des arts et métiers (Le Cnam),

1 boulevard Pythagore, Le Mans F-72000, France

D. Ramier

CEREMA, Département Ville Durable, 12 rue Teisserenc de Bort, Trappes cedex 78197, France content and tensiometer probes, confirming that the saturation rate is controlled by infiltration and not the water table.

Keywords Hydraulic conductivity · Colluvium soil · Hydrodynamic properties - Soil texture - Pedotransfer function

\section{Introduction}

On-site domestic sanitation is a management mode to treat the wastewater. It can be executed by different methods. The decision to choose a method is made according to local conditions of the site. These standard methods ensure the collection, treatment and evacuation of domestic wastewater, near the house.

In France, 5.4 million homes, nearly $15 \%$ of the population uses this system to purify the domestic wastewater. In general, the on-site treatment system (UOSTS) will be designed, installed and maintained so as to present no risk of soil contamination or water pollution. It should be noticed that the treated wastewater can be reused for watering the yard gardens or any special use such as shellfish farming and swimming (Brigand and Lesieur 2008).

The contaminants in the soil do not necessarily move at the same rate as water. But the transit time of water represents a lower limit of transport time of certain contaminants. Otherwise, it is important to know and describe the terms of water flow in soil under a sand pack (infiltration system) in order to characterize the soil capacity to allow to transport the residual dissolved and suspended substances (Calvet 2003).

Current recommendation for the design and management of infiltration structures of treated wastewater and 
storm water runoff are mainly based on hydraulic criteria of the structure. So far, little data are available with regard to the intensity of the disturbance caused by the heterogeneity of subsurface soil.

The analysis of the signals of water content and matrix potential of soil allows understanding the influence of an undrained on-site treatment system (UOSTS), with a sand filter and distribution drains, on the water flow distribution in underlying soil.

Infiltration of treated waters may greatly depend on large continuous openings (macropores) in field soils. Such voids are sometimes known to be continuous for distances of at least several metres in the vertical and lateral direction. These voids allow for rapid movement of water, solutes and pollution through the soil.

Researchers have not yet reached an agreement on the definition of macropores (Beven and Germann 1982; Flury et al. 1994). According to certain publications, a macropore is generally regarded as a pore with a radius ranging from 0.03 to $3 \mathrm{~mm}$ (Beven and Germann 1982; Liu et al. 2001). Thus complex relationship is expected between void geometry and flow characteristics at some microscopic scales.

It is more probable that water moves through large pores under saturated conditions and this influence the saturated hydraulic conductivity of soils, even though they may slightly contribute to the total porosity of soil. When structural pores are larger than those attributed to the soil matrix, the movement of water through the macropores, once initiated, may be much faster than equilibration of potentials in a respective volume of soil matrix. In this case, the potential gradients associated with the two types of pores will be different.

In clayey soils, the clay particles themselves cohere, entrap or bridge between larger sand and soil grains and compose the aggregates. These types of binding are all important and pathways are created between them (the preferential pathways); a portion of the water is percolated by these macropores before the body of the soil has become saturated; this is especially the case if rain falls quickly or there is flash flow infiltrating in the soil (Lawes et al. 1982). From a certain clay and silt content, soils tend to crack (macropores) and this phenomenon can be expected to a certain extent using the following formula proposed by Hénin (1976), $2 C+L>60$; where $C$ is the clay content and $L$ is the silt content.

Another cause of development of macropores is due to the presence of the rock fragments (stones) in the soil. The rock fragment is generally defined as all particles larger than $2 \mathrm{~mm}$ (Gee and Or 2002; Soil Survey Staff 2010). Therefore, the word "stones" is employed to designate this fraction. According to Tetegan et al. (2011), stony soils are soils containing over $35 \%$ in volume of soil particles larger than 2 mm (FAO 2006; Soil Survey Staff 2010). Approximately $30 \%$ of the lands in Western Europe and $60 \%$ in the Mediterranean area are covered by these soils (Poesen and Lavee 1994; Cousin et al. 2003). The wide distribution of this type of soil makes a great interest in how it functions, but characterizing stony soils remains difficult.

Two objectives have been envisaged for this paper: (1) the methodology of conception and realization of an $U$ OSTS pilot site; (2) valorisation of this installation by studying the terms of water flow in the underlying stony soil. The first objective is valid for any kind of soil and the second one arises from the local and technical conditions of this pilot site which is specific to the type of soil which we faced in this site. In order to provide some explanations, a literature review on the effect of stones in the soil on physical and hydraulic properties of the soil is presented in the state of the art. These objectives turn around the evaluation of infiltration imposed by an UOSTS into the underlying heterogeneous stony soil which is addressed to find the appropriate answers to the following questions:

- Is it possible to identify the effect of embedded stone fragments on soil hydraulic conductivity?

- What variability in infiltration rates can be expected under an UOSTS which is characterized by heterogeneous, stony soil, with a fine soil matrix between the stone fragments?

- What is the influence of the UOSTS on the spatial distribution of the infiltration rate in the underlying soil?

State of the art

Stones play an important role in the soil as they modify its pore space. In natural soils, an increase in the content of stone fragments is correlated to a decrease in the bulk density of fine soil matrix (Torri et al. 1994). This decrease is due to extra porosity resulting from contact between the stones and the fine soil matrix, which in turn takes place because the space between the stones is partially filled with fine soil matrix or because the larger particles prevent the smaller ones from packing (Stewart et al. 1970; Poesen and Lavee 1994). In very humid state, stones affect the pore space of the mixtures only if there are many of them, although Spomer (1980) suggested that drying the mixtures that contain a clay soil leads to the formation of pores as a result of the shrinkage of fine soil matrix between stones. Moreover, in stony soil with clay content greater than $30 \%$, the aggregation and shrinkage of the fine matrix leads to the formation of macropores due to cracking (Towner 1988; Fiès et al. 2002). Such pores will modify the soil water retention capacity compared with soil without stone. 
Stone fragment content, size and position in the soil, may affect infiltration. The presence of stone fragments at the soil surface usually results in a decrease in the infiltration rate (Childs and Flint 1990; Ma et al. 2010; Ma and Shao 2008) since they reduce the surface available for flow transport in soil. Nevertheless, stone fragments can also increase the infiltration rate, by the creation of preferential flow (PF) pathways at the soil matrix-stone interface; the latter is effective only at high water content.

Shi et al. (2012) showed that the increase in the volumetric content of stones in soil increases the average radius of macropores and the density of macropores; thus, it increases the rate of infiltration.

Urbanek and Shakesby (2009) argued that, in the case of large stone contents, flow pathways develop along sand-stone interfaces and can provided continuous PF paths as there are sufficient stone-to-stone connections. The distribution and alignment of the stones, especially at an intermediate stone content, are important for promoting water movement. Zhou et al. (2009) studied the effects of different stone fragment contents in a soil on infiltration, saturated hydraulic conductivity $K_{\mathrm{s}}$ and solute transport. The in situ tests showed that both infiltration rates and the saturated hydraulic conductivity initially decreased with increasing stone fragment content to minimum values and then increased. Verbist et al. (2012) demonstrated that stone fragment content is correlated significantly to both saturated and unsaturated conductivities, probably due to a positive correlation between stone content and coarse lacunar pore space. In a numerical modelling which was conducted by Cousin et al. (2003), in calcareous soils, they found that percolation was underestimated when the stone fragments were neglected and the soil was considered only as fine earth.

Gómes et al. (2001) used four different measurement methods (falling-head well permeameter, pressure infiltrometer, tension infiltrometer, and rainfall simulator) for measuring the infiltration rate of soil. They were able to detect significant differences in infiltration rates between and under olive trees in southern Spain with each of the methods used which is related to the extension of the roots under the trees and so creation of PF in soil.

Techniques for describing, inferring, or quantifying PF can be classified into four groups: (1) observing and quantifying structures likely to cause PF; (2) measuring water distribution or water movement; (3) investigating gas movement and (4) analysing images. Different techniques in each group can be described with different advantages and disadvantages. An extensive description of each technique was discussed by Allaire et al. (2009).

\section{Materials and methods}

Field site

The field site of this study is located in a little valley in France $\left(03^{\circ} 26^{\prime} 28.3^{\prime \prime} \mathrm{E}, 47^{\circ} 39^{\prime} 52.8^{\prime \prime} \mathrm{N}\right)$ and it consists of a soil with a fine matrix containing stone fragments. This heterogeneous soil developed on calcareous parent material of the Upper Jurassic which is common in the Paris Basin. In terms of lithology, the stone fragments of the site are of the Portlandian limestone. Because of the relatively steep slope at both side of the valley (the site is located at the foot of this slope), it seems that the soil is a colluvium which is the result of the movement and accumulation of fragments issued from the Portlandian layer (J9) deposited on Kimmeridgian marls. The colluvium made of a clay loam soil with the calcareous fragments, has been accumulated at the surface along the limit between the outcrops of the two geological units. According to United stated department of agriculture (USDA) soil classification, it is an Entisoil. In this soil, the absence of pedogenic horizons may be the result of an inert parent material, such as quartz sand, in which horizons do not readily form; slowly soluble, hard rock, such as limestone, which leaves little residue; insufficient time for horizons to form, as in recent deposits of ash or alluvium; occurrence on slopes where the rate of erosion exceeds the rate of formation of pedogenic horizons; recent mixing of horizons by animals or by ploughing to a depth of 1 or $2 \mathrm{~m}$; or the spoils from deep excavations (Fig. 1).

The UOSTS ensures independent collection, treatment and evacuation of domestic wastewater near the house by spreading the pre-treated wastewater in five drains on a sand pack and then the treated wastewater percolates in the soil under the system (Figs. 2, 3). The bottom of the excavation of a new UOSTS in the yard of a house was selected to collect soil water, collect the soil samples, and carries out the permeability tests and to install the hydrodynamic monitoring probes (Nasri et al. 2012).

\section{Field measurements}

At the beginning of installing the UOSTS, the bottom of the excavation $(120 \mathrm{~cm}$ depth) was gridded into 25 square meshes of $1 \mathrm{~m}^{2}$ and then 15 soil samples were collected from the first $15 \mathrm{~m}^{2}$ of the excavation (1 sample of $10 \mathrm{~kg}$ for each $\mathrm{m}^{2}$ on average). Simultaneously, in the middle of the each $\mathrm{m}^{2}, 15$ permeability tests were done with a Guelph permeameter device in order to measure the local saturated hydraulic conductivity $K_{\mathrm{s}}$ of the soil.

Concerning the $K_{\mathrm{s}}$ measurements, it is important to consider the measurement method and the subsequent data 


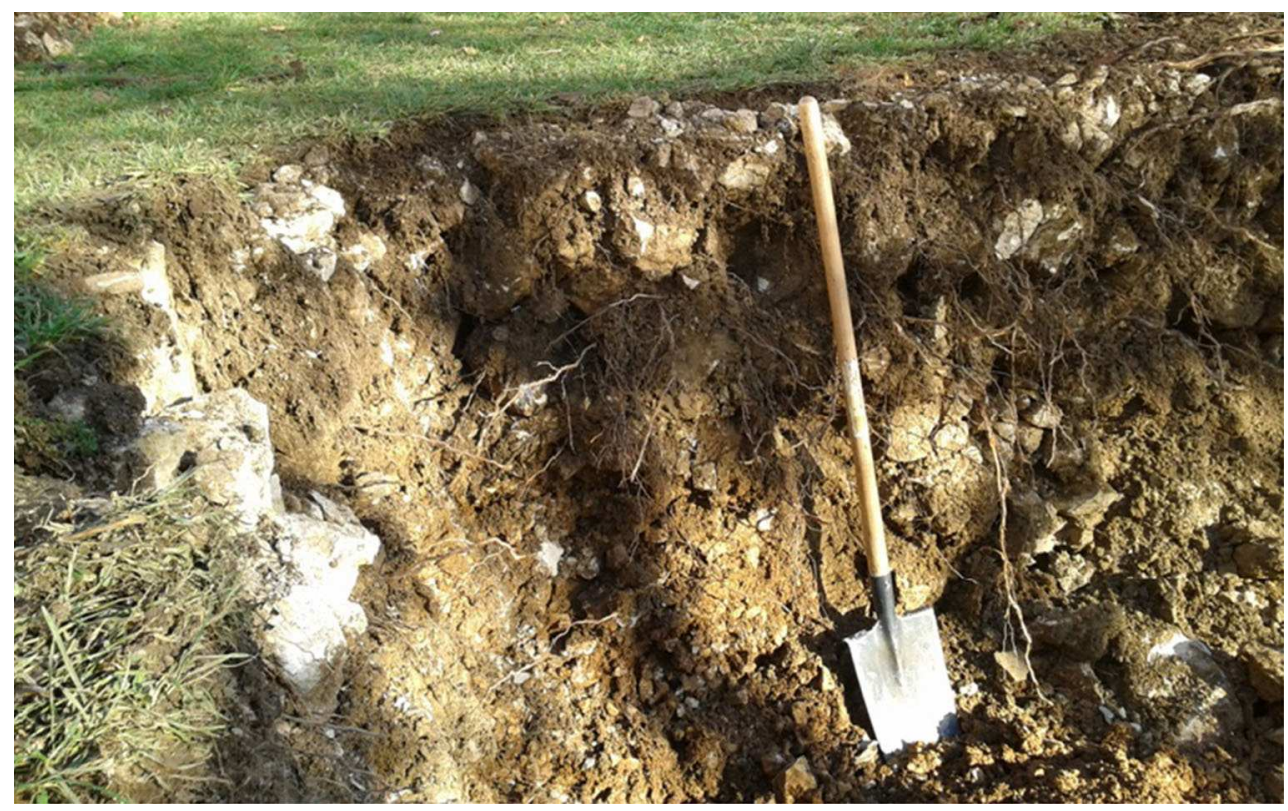

Fig. 1 Soil profile of the pilot site. The heterogeneous mixture of pebbles and fine soil in absence of horizon

Fig. 2 General view of the pilot UOSTS and instruments

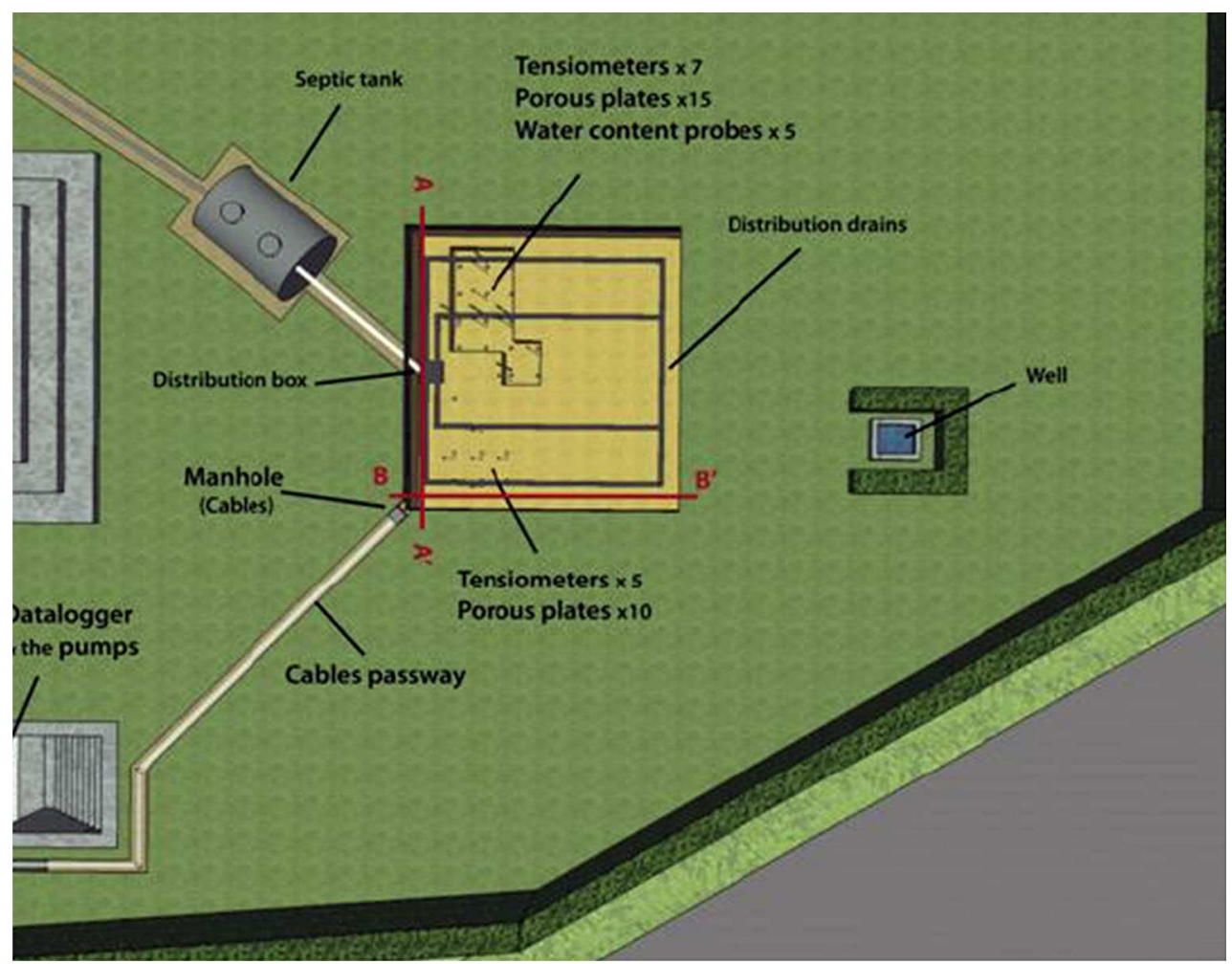

analysis. Reynolds et al. (2000) compared three methods: pressure infiltrometer, tension infiltrometer, and the constant-head soil core method to determine saturated hydraulic conductivity and found very little correlation among the methods used. Mohanty et al. (1994) observed similar differences when comparing the constant-head well
(Guelph) permeameter, falling-head well permeameter, tension infiltrometer, concentric ring infiltrometer, and constant-head soil core methods.

After Elrick et al. (1989) the hydraulic conductivity by Guelph permeameter is calculated with the following equation: 


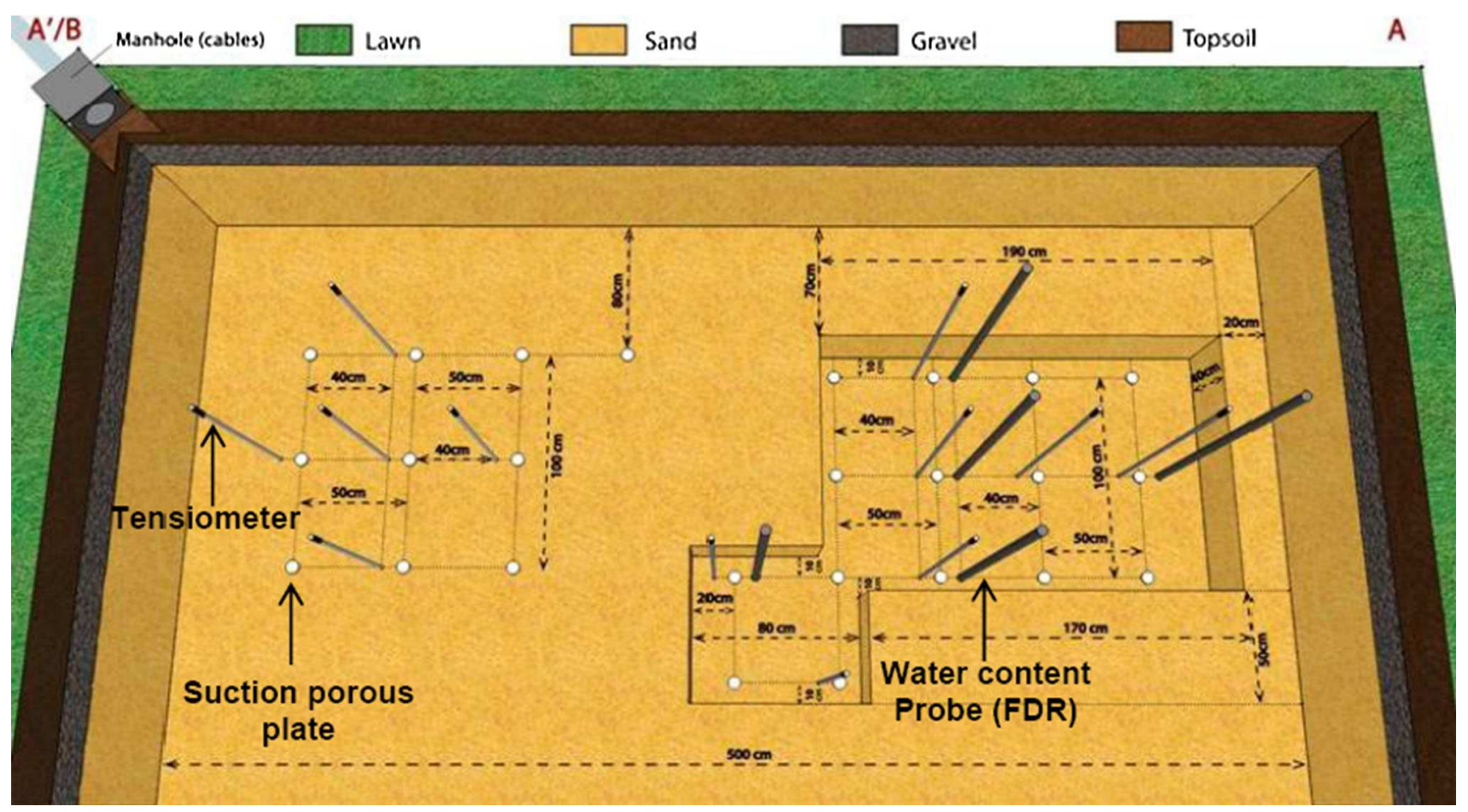

Fig. 3 Plan of the probes set up at the bottom of the excavation

$K_{s}=Q /\left(A+\left(B / \alpha^{*}\right)\right)=C Q /\left(2 \pi H^{2}+\pi a^{2} C+2 \pi H / \alpha^{*}\right)$

where $Q\left(L^{3} \mathrm{~T}^{-1}\right)$ is the steady intake rate of water, $H(L)$ is the constant height of the ponded water in the well, $\alpha^{*}$ take on specific forms for specific solutions, $K_{\mathrm{S}}\left(L \mathrm{~T}^{-1}\right)$ is the field saturated hydraulic conductivity, $C$ is a dimensionless shape factor and $A$ and $B$ are the coefficients.

The "Achilles heel" in the above approach is the choice of $\alpha^{*}$. Elrick et al. (1989) noted that the $\alpha^{*}=12 \mathrm{~m}^{-1}$ is the first choice for most soils. Actually, according to the results of laboratory tests on soil samples (stony calcareous soil with a clay loam matrix) value $\alpha^{*}=12 \mathrm{~m}^{-1}$ was considered in our calculations of $K_{\mathrm{s}}$ by the Guelph permeameter.

Installation of hydrodynamic detecting devices in the field site

According to the methods proposed by Weihermuller et al. (2007) for interstitial water sampling, a series of porous suction plate was selected: 10 suction plates collected soil water at $120 \mathrm{~cm}$ depth and 15 plates at $160 \mathrm{~cm}$. Finally, they were all covered with the excavated soil. Water was collected separately from each set of plates by two vacuum pumps, via small Teflon tubes. With a suction of $500 \mathrm{hPa}$, $100 \mathrm{ml}$ of infiltrated water per hour can be collected. A rough calculation of the recoverable amount of water leads to a conservative value of $1.2 \mathrm{l} / \mathrm{day} / \mathrm{resident}$. This value is for low matrix potential of soil between 0 and 100 mbar. This installation is an essential and operational part in the conception of the pilot site. For the second objective of this paper, however, the water samples analysis is not used and it has been analysed in another paper which is in preparation.

In order to characterize the hydrodynamic changes imposed by infiltrated wastewater and rainfall in the soil under the UOSTS, the spatial distribution of the water content and the matrix potential of the soil were monitored under the bottom of the excavation at two depths (120 and $160 \mathrm{~cm}$ ). The system was composed of 12 electronic tensiometers (5 at $120 \mathrm{~cm}$ and 7 at $160 \mathrm{~cm}$ ) (SDEC-France company; model: STCP 850) and 5 water content profiling probes (SoilMoisture Ltd.) which transmit an electromagnetic field extending about $100 \mathrm{~mm}$ into the soil as a ring at 6 given depths (Delta-T Devices Co; model PR2/6-FDR). Twelve electronic tensiometers provided longitudinal and transversal matrix potential profiles across the soil. The water content probes measure the temporal and spatial distribution of volumetric water content of soil at 70, 80, $90,100,120$ and $160 \mathrm{~cm}$ of depth from the soil surface. A pressure sensor of free water table (STS, DL/N series 70) was installed in a well downstream of the plot. This device was completed by a meteorological station (Watchdog 2900ET) near the plot which measures the rainfall and four other parameters. The data were continuously recorded by 
data loggers (time step of $30 \mathrm{~min}$ for rain, $10 \mathrm{~min}$ for soil tension and water content and $1 \mathrm{~h}$ for the water table) (Figs. 2, 3).

Among the different techniques of describing and inferring the $\mathrm{PF}$ in this site, three techniques were used in this study: (1) observation of the excavation measuring; (2) field saturated hydraulic conductivity in multiple points; and (3) water content and matrix potential distribution.

Observing the soil structure may range from a very expensive method (e.g. scanning) to an inexpensive one (e.g. photo of soil surface). We selected the direct observation of the excavation at a rainy period to search the water trickles between stone fragments. The field saturated hydraulic conductivity measurements in 15 points were done by a Guelph permeameter as explained above. The water content and tension distribution technique is a simple technique, easy to measure but difficult to interpret and install, which was done by the FDR probes and the tensiometers. By a graphical interpretation of processed data, we estimated the spatial heterogeneity and the PF interpreted from this heterogeneous distribution.

\section{Textural characterisation and pedotransfer functions}

In the geotechnique laboratory, the 15 soil samples have been oven dried $105{ }^{\circ} \mathrm{C}$ for $24 \mathrm{~h}$. The fine earth fraction (soil matrix) was separated from the stone fragments by softly brushing and grinding. The organic matter (OM) content was determined by combustion. The average of OM for the soil samples is $4.28 \%$. According to the results of specific surface (Ss) determination, the average of Ss for the soil matrix of pilot site is $88.7 \mathrm{~m}^{2} / \mathrm{g}$ and so the cation exchange capacity can be estimated to be $14 \mathrm{meq} / 100 \mathrm{~g}$ averagely. The soil matrix was put through on the $0.08 \mathrm{~mm}$ sieve. For each of the samples, according to the standards, sedimentometry tests were done for the particles lower than $0.08 \mathrm{~mm}$. Following the particle size distribution curve which was derived for each soil sample, soil texture of the samples was determined by using the USDA soil texture triangle (Fig. 5). The average of the stone content of the soil samples is $52 \%$ and the variation coefficient of stone fragment content is $13 \%$ for the soil samples. The values of measured $K_{\mathrm{s}}$ are presented in Fig. 4.

In addition, hydraulic conductivity $K_{\mathrm{s}}$ was also estimated for each soil sample by using these textural data and applying pedotransfer functions (PTFs). In the field of soil science, a pedotransfer function (PTF) is a tool based on statistical relationship, used to estimate and predict the properties and behaviour of soil which are difficult to measure directly, from other soil characteristics which are observable in the field or determined by routine tests on soil samples in laboratory. Hydraulic conductivity of the soil was estimated by three PTFs developed by Cosby et al. (1984), Ferrer-Julià et al. (2004) and Adhikary et al. (2008):

$$
\begin{aligned}
& K_{\mathrm{s}}=7.05556 \times 10^{-6} \times 10^{(-0.6+0.0126 \times S-0.0064 \times C)} \\
& K_{\mathrm{s}}=4.82 \times 10^{-6} \times(L+C)^{-1.48} \\
& K_{\mathrm{s}}=2.556 \times 10^{-7} \exp (0.0491 \times S)
\end{aligned}
$$

where $K_{\mathrm{s}}(\mathrm{m} / \mathrm{s})$ is the saturated hydraulic conductivity, $S$, $L$ and $\mathrm{C}$ are, respectively, the percentages of sand, silt and clay in the soil. These PTFs have been established just by the soil mineral fractions and they do not consider the OM of soil as predictor. In the case of the soil of this study, they are the much realistic estimators because of the low OM content of soil samples and the depth of the measurement horizon which is below $120 \mathrm{~cm}$ of the soil surface.

\section{Results and discussion}

\section{Measured and estimated hydraulic conductivity}

The three PTFs predict $K_{\mathrm{s}}$ from the texture of the soil. So this permeability is directly related to the fine soil matrix. In addition, these PTFs were developed for homogeneous soils. On the other hand, hydraulic conductivity which was measured by the Guelph is overall permeability of the soil that includes the effect of the coarse and fine fractions of the soil (Lee et al. 1985).

Table 1 shows the texture of the samples, the $K_{\mathrm{s}}$ measured in situ by Guelph and $K_{\mathrm{s}}$ predicted by PTFs of Cosby, Ferrer-Julià and Adhikary. According to the results, the majority of the samples had remarkable clay and silt fractions (on average 37 and $38 \%$, respectively) and had a clayey loam texture. The $15 K_{\mathrm{s}}$ predicted by 3 PTFs varied less than measured ones because the texture was more or less homogeneous. Spatial variability (two orders of magnitude) of the $15 K_{\mathrm{s}}$ measured by Guelph was considerable and this variability followed no pattern. The average of 15 measured $K_{\mathrm{s}}$ by Guelph was, respectively, 51, 123 and 134 times larger than those predicted by the PTFs of Cosby, Ferrer-Julià and Adhikary.

\section{Monitoring the hydrodynamic parameters}

Figures 6 (left, right), 7 (left, right), are a graphical presentation of variations of the volumetric water content $(\%)$, soil tension (negative m_water) or pressure (positive m_water) for a very short dry period at 2 depths, and water table $(\mathrm{m})$ and rainfall $(\mathrm{mm})$ for a 1 month wet period.

Figure 6 (left) is an illustration of the soil water tension for the 5 tensiometers installed at $120 \mathrm{~cm}$ from July 29th to 
Fig. 4 Variation of $K_{\mathrm{s}}$ values measured by Guelph permeameter at $120 \mathrm{~cm}$ depth

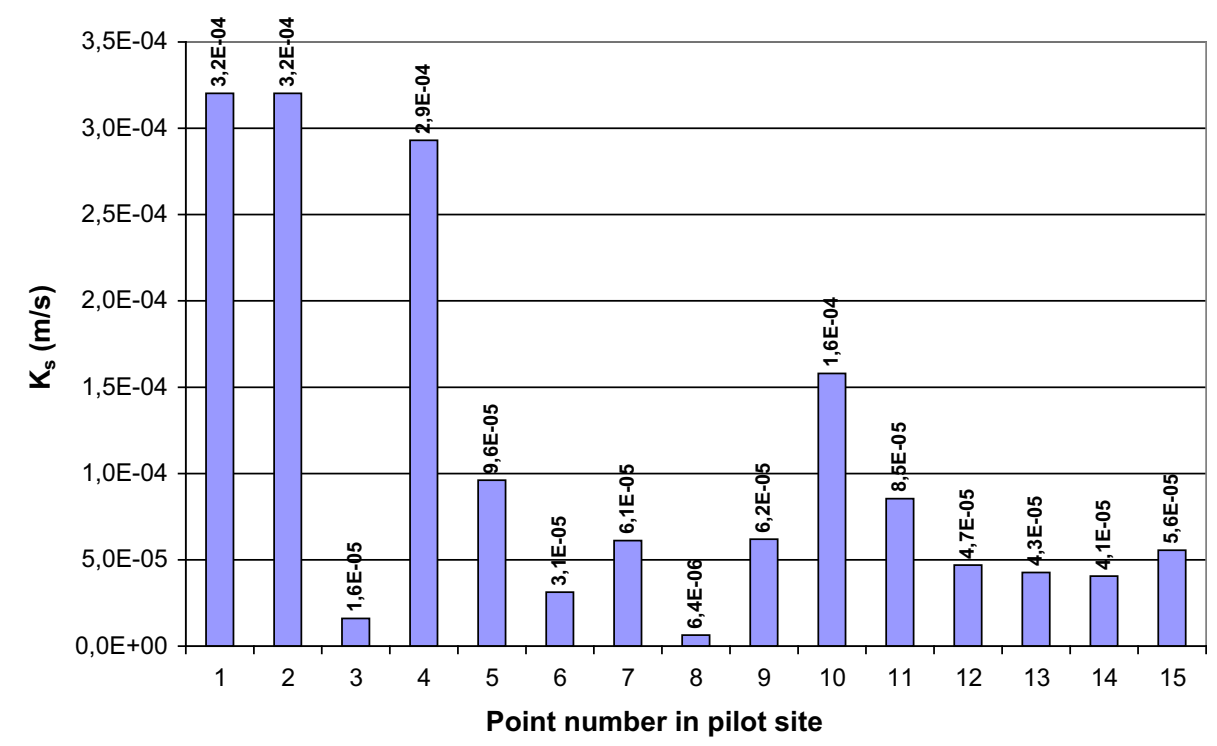

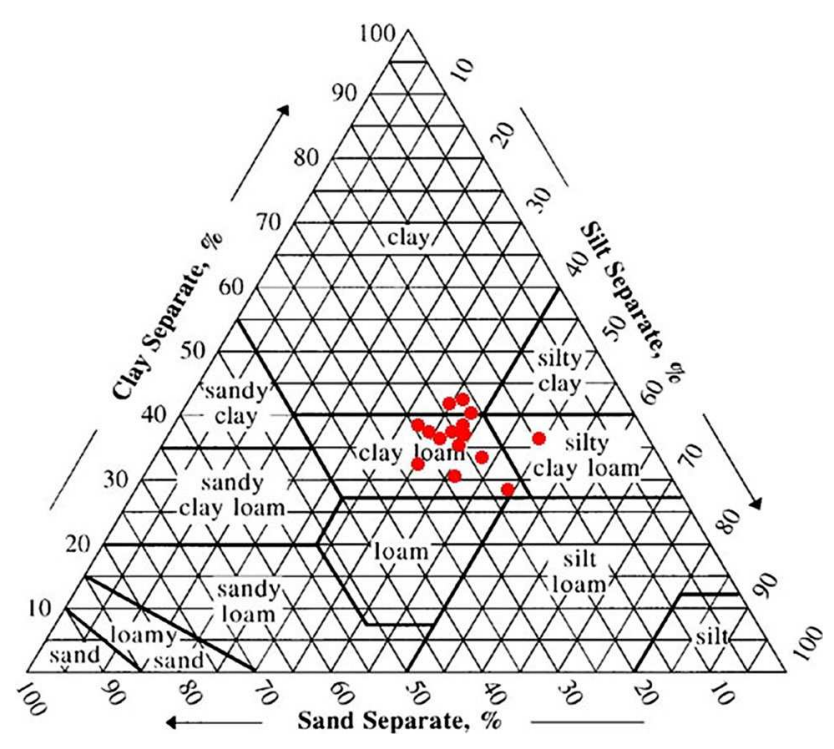

Fig. 5 Variation in clay $(0-2 \mu \mathrm{m})$, silt $(2-50 \mu \mathrm{m})$, and sand $(>50 \mu \mathrm{m})$ contents at the 15 measurement points

August 2nd. They were located at the interface of sand and soil. The pressure values of $\mathrm{T} 8, \mathrm{~T} 9$ and $\mathrm{T} 11$ were very positive and $\mathrm{T} 10$ and $\mathrm{T} 12$ were almost near-zero tensions. This means that the porous media at the interface is relatively saturated. For all the tensiometers there is daily cycle with two main peaks at 13:00 and 23:00 which are compatible with the peak time of consumption of water by the inhabitants at home. The identical temporal behaviour of $\mathrm{T} 10$ and $\mathrm{T} 12$ together and $\mathrm{T} 8, \mathrm{~T} 9$ and $\mathrm{T} 12$ indicated that they received the same sequences with varying amounts of water. The spatial variation of the pressure in this part is due to the non-homogeneous distribution of treated wastewater in the drains, which are implanted parallel with a distance of $1 \mathrm{~m}$ one to another, but the spatial distribution was complicated and this could also be explained by the heterogeneous vegetated soil above the drains which could cause heterogeneous evaporation from the soil. The range of variation of pressure, in the tensiometers, was between 0 and $1 \mathrm{~m}$-water on average.

Figure 6 (right) is the same dry period as (Fig. 6, left) but shows the variation of four tensiometers (T2, T3, T5 and $\mathrm{T} 6$ ) at $160 \mathrm{~cm}$ in the soil. The pressure values of $\mathrm{T} 2$, $\mathrm{T} 3$ and $\mathrm{T} 4$ are positives or near to zero (T6). The daily cycles can be seen in this part too. But the range of the variation of the pressure is between -0.25 and 0.5 $\mathrm{m}$-water which is less than values in $120 \mathrm{~cm}$. This phenomenon can have several reasons. The drains above the $160 \mathrm{~cm}$ depth (right side of the UOSTS) may contain more treated wastewater than the drains above $120 \mathrm{~cm}$ depth (left right of the UOSTS) and this is because of the installation of the drains (right and left is in the absolute direction of the installation of the system, which means a view form upstream to downstream. On the other hand, the results of the soil hydraulic conductivity measurements show that the permeability of the soil was at the same order of magnitude as that for sand in $10^{-4} \mathrm{~m} / \mathrm{s}$ and while the soil has a clay loam texture. This surprising high value of measured $K_{\mathrm{s}}$ demonstrates the preferential flow due to the soil heterogeneity. In addition to the non-uniform distribution of infiltrated water, the general difference among the pressure of the tensiometers is due to the heterogeneity of soil.

The non-uniform spatial distribution of pressure potential for all tensiometers and their daily cycle oscillation, which were almost all positive for all of them, shows that the saturation was controlled by infiltration from the upper layer infiltration-controlled saturation and this is not due to 
Table 1 The measured (Guelph) and predicted $\left(K_{\mathrm{s}}\right.$ PTFs) $K_{\mathrm{s}}$ of the soil samples

\begin{tabular}{llllll}
\hline Soil & Textural class & $K_{\mathrm{s}}(\mathrm{m} / \mathrm{s})$ & $K_{\mathrm{s}}$-Cosby $(\mathrm{m} / \mathrm{s})$ & $K_{\mathrm{s}}$-Adhikary $(\mathrm{m} / \mathrm{s})$ & $K_{\mathrm{s}}$-Ferrer-Julià $(\mathrm{m} / \mathrm{s})$ \\
\hline 1 & Clay loam & $3.20 \mathrm{E}-04$ & $2.08 \mathrm{E}-06$ & $8.01 \mathrm{E}-07$ & $8.51 \mathrm{E}-07$ \\
2 & Clay & $3.20 \mathrm{E}-04$ & $1.83 \mathrm{E}-06$ & $7.63 \mathrm{E}-07$ & $7.53 \mathrm{E}-07$ \\
3 & Clay loam & $1.60 \mathrm{E}-05$ & $2.38 \mathrm{E}-06$ & $8.95 \mathrm{E}-07$ & $1.12 \mathrm{E}-06$ \\
4 & Clay loam & $2.93 \mathrm{E}-04$ & $2.84 \mathrm{E}-06$ & $9.55 \mathrm{E}-07$ & $1.29 \mathrm{E}-06$ \\
5 & Clay & $9.61 \mathrm{E}-05$ & $1.90 \mathrm{E}-06$ & $7.93 \mathrm{E}-07$ & $8.30 \mathrm{E}-07$ \\
6 & Clay loam & $3.13 \mathrm{E}-05$ & $2.15 \mathrm{E}-06$ & $7.93 \mathrm{E}-07$ & $8.30 \mathrm{E}-07$ \\
7 & Clay & $6.12 \mathrm{E}-05$ & $1.78 \mathrm{E}-06$ & $7.63 \mathrm{E}-07$ & $7.53 \mathrm{E}-07$ \\
8 & Clay loam & $6.41 \mathrm{E}-06$ & $2.22 \mathrm{E}-06$ & $8.25 \mathrm{E}-07$ & $9.16 \mathrm{E}-07$ \\
9 & Clay loam & $6.19 \mathrm{E}-05$ & $2.35 \mathrm{E}-06$ & $8.77 \mathrm{E}-07$ & $1.06 \mathrm{E}-06$ \\
10 & Clay loam & $1.58 \mathrm{E}-04$ & $2.00 \mathrm{E}-06$ & $7.93 \mathrm{E}-07$ & $8.30 \mathrm{E}-07$ \\
11 & Silty clay loam & $8.54 \mathrm{E}-05$ & $1.59 \mathrm{E}-06$ & $6.72 \mathrm{E}-07$ & $5.34 \mathrm{E}-07$ \\
12 & Clay loam & $4.70 \mathrm{E}-05$ & $2.25 \mathrm{E}-06$ & $7.78 \mathrm{E}-07$ & $7.91 \mathrm{E}-07$ \\
13 & Clay loam & $4.27 \mathrm{E}-05$ & $2.60 \mathrm{E}-06$ & $8.77 \mathrm{E}-07$ & $1.06 \mathrm{E}-06$ \\
14 & Clay loam & $4.06 \mathrm{E}-05$ & $2.15 \mathrm{E}-06$ & $8.25 \mathrm{E}-07$ & $9.16 \mathrm{E}-07$ \\
15 & Clay loam & $5.55 \mathrm{E}-05$ & $2.31 \mathrm{E}-06$ & $8.59 \mathrm{E}-07$ & $1.01 \mathrm{E}-06$ \\
Average & Clay loam & $1.09 \mathrm{E}-04$ & $2.14 \mathrm{E}-06$ & $8.13 \mathrm{E}-07$ & $8.85 \mathrm{E}-07$ \\
\hline
\end{tabular}

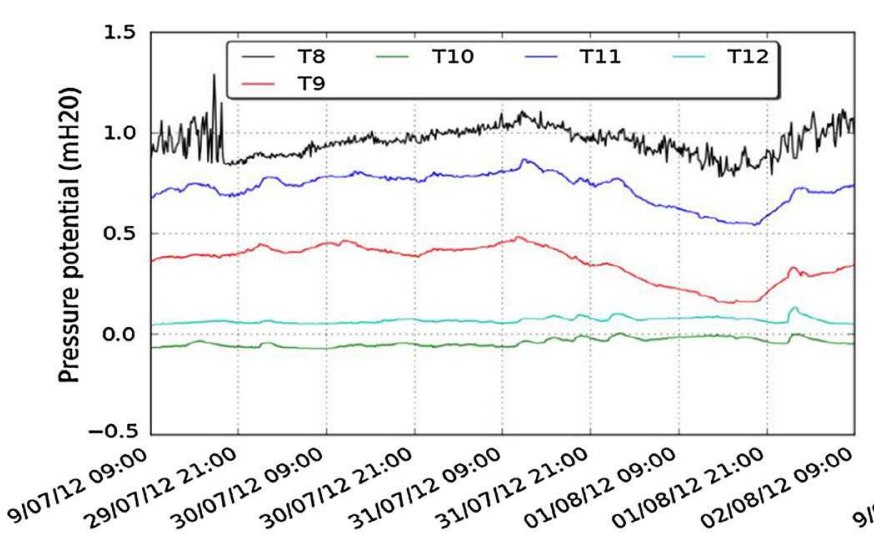

Date

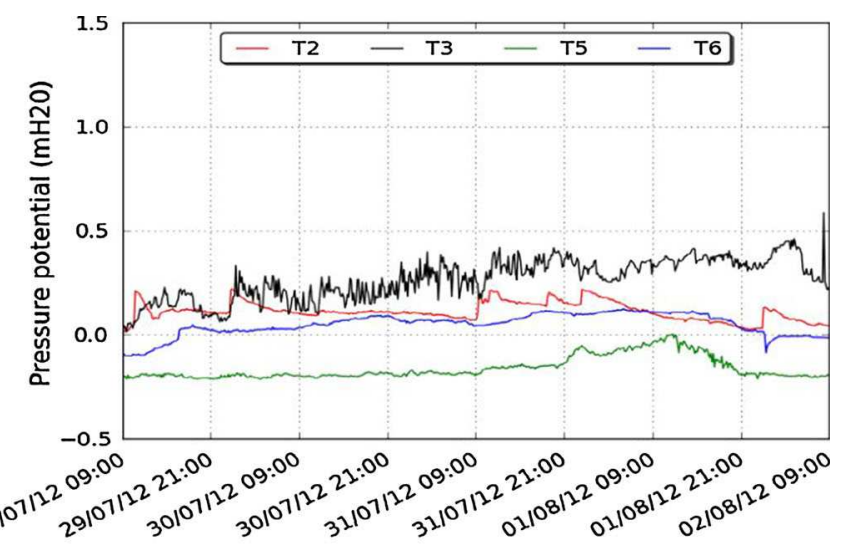

Date

Fig. 6 Pressure potential variation of tensiometers at $120 \mathrm{~cm}$ depth (left). Pressure potential variation of tensiometers at $160 \mathrm{~cm}$ depth (right)
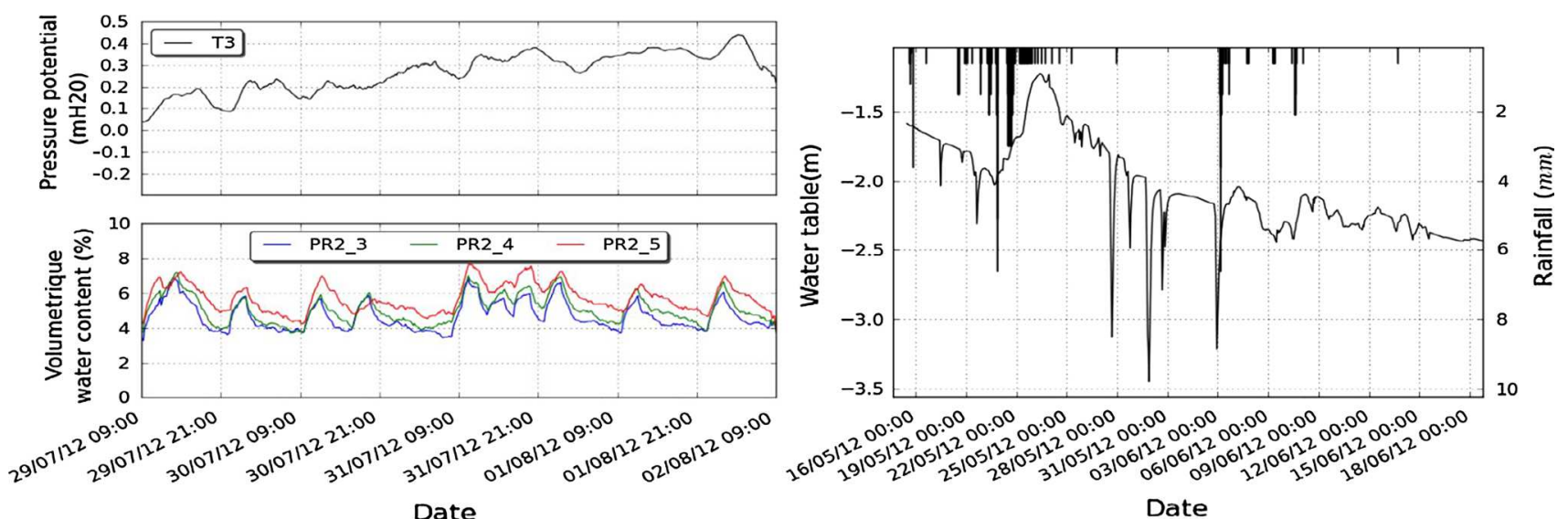

Fig. 7 Temporal changes in soil tension (T3) and water content (PR2) at mesh number 2 (left). Variation of the water table and rainfall for a period of 1 month (right) 
the rise of water table which would creates a flat free surface with a homogenous water head in different depths.

The development of soil water content (PR2) at three depths (90 and $100 \mathrm{~cm}$ in the sand pack and $120 \mathrm{~cm}$ at the sand-soil interface) and soil water tension (the nearby implanted tensiometer, T3) are illustrated in (Fig. 7, left). The two devices were placed side by side $(20 \mathrm{~cm}$ of distance at mesh $\mathrm{n}^{\circ} 2$ ). The two daily peaks of water content due to infiltration of treated wastewater are observable on the PR2 curve which corresponds to the variation of water tension of the soil recorded by $\mathrm{T} 3$ over the same time period. According to the three curves of water content variation, the vertical gradient in three depths shows that the water content varied between 4 and $7.5 \%$ every day and the water content increased in depth, with approaching the water table.

By using water table variation data and rainfall data for a pluvial period which is illustrated in (Fig. 7, right), we can observe a clear reaction of the water table to the rain with a progressive rise of the water table as it took some time due to the time that the water needs to flux downward through the soil and arrive at the water table. This means that there is a rapid hydraulic relationship between the infiltrated surface water and the water table.

\section{Conclusion}

A real undrained on-site treatment system (UOSTS) was successfully instrumented for evaluation of the role of the soil under the treatment system, for the first time at the authors knowledge. The suction plates collect the soil water regularly and the probes highlight the hydraulic functioning of the UOSTS and also the hydrological and meteorological phenomena. Comparison of chronics of water content and the matrix potential and the analysis of their spatial variation were made. Once the probes are successfully installed, the chronics are easy to get. The spatial variation of the water content of a probe to the others, and the matrix potential of tensiometers to the other, shows the existence of heterogeneity preferential paths under the UOSTS.

The variation of 15 measured $K_{\mathrm{s}}$ by Guelph permeameter demonstrates the heterogeneity in the soil which causes the non-uniform infiltration of water on $15 \mathrm{~m}^{2}$ area which leads to the concept of meshes with preferred permeability. At the same time, the texture of the soil shows that the fine soil matrix of the 15 samples does not vary significantly and the soil has a clay loam texture on average. Following the results of the three pedotransfer functions (PTFs), the $K_{\mathrm{s}}$ associated to the soil texture is on average two orders of magnitude lower than the $K_{\mathrm{s}}$ measured in situ by Guelph which could turn to be a general result for stony soils. Otherwise, the PTFs with OM as predictor have not been examined in this type of soil. In addition, the existence of high clay and silt fractions result in $2 C+L>60$, where the effect of drying and humidification could lead to the construction of aggregates with pore spaces (fissures) that constitute another level of macropores of structural porosity. At the depth of $120 \mathrm{~cm}$, no roots or animal holes were observed. This leads to the overall conclusion that the stone fragment content is the most important factor which results in a remarkable variation of the infiltration rates in the soils in our experimental plot. It is in the case that the soil matrix exhibits only small textural differences. As a conclusion, the macropores created by presence of the stones and high content of clay and silt are responsible for the high average saturated hydraulic conductivity of the soil. The $K_{\mathrm{s}}$ with two orders of magnitude higher than the homogeneous soil matrix indicate a type of PF and in addition, the spatial distribution of $K_{\mathrm{s}}$ indicates a non-uniform distribution of macropores. In spite of our assumption at the beginning, the other PTFs with $\mathrm{OM}$ as predictor are to be tested in order to verify if this parameter has an impact on hydraulic conductivity in this type of soil. The effect of karst in the substratum was not taken into account in this study, but it could be another source of PF in this type of soil.

The pilot site highlights the existence of preferential pathway fluxes due to the heterogeneity of both the hydraulic solicitation and the stony soil texture. This methodology, here applied in complex soil conditions, will be reproducible within other soils, especially in more homogeneous soils, and for greater scale UOSTS.

This stony soil is representative of a large part of the soils in this area. This conclusion can probably be extended to stony soils of other calcareous regions and beyond, to heterogeneous urban soils that are more or less anthropogenic. This implies that stone fragment content should be taken into account when hydrologic processes are evaluated and when developing PTFs to predict hydraulic properties.

As a perspective, the results of the permeability tests can be coupled with the chemical analysis results of soil water samples which were collected in two levels (120 and $160 \mathrm{~cm}$ ) by porous plates that had been installed on the underlying soil at the bottom of the on-site treatment excavation, to evaluate the impact of soil on the quality of percolated water toward the water table.

The existing hydraulic relationship between the water table and rainfall is very important in terms of the environment. The contaminant retained in the sand pack or in the soil below the sand pack can be transported from the unsaturated area below the UOSTS to the water table by the flash and continuous short rainfall through preferential pathways. 
Acknowledgments For their financial support, the authors would like to thank the GESSOL program (French Ministry of Ecology, ADEME) through the ANCRES project, and the French Ministry of Foreign Affairs.

\section{References}

Adhikary PP, Chakraborty D, Kalra N, Sachdev CB, Patra K, Kumar S, Tomar P, Chandna D, Raghav K, Agrawal RK, Sehgal M (2008) Pedotransfer functions for predicting the hydraulic properties of Indian soils. Aust J Soil Res 46:476-484

Allaire SE, Stéphanie SB, Cessna AJ (2009) Quantifying preferential flow in soils: a review of different techniques. J Hydrol 378:179-204

Beven K, Germann P (1982) Macropores and water flow in soils. Water Resour Res 18:1311-1325

Brigand S, Lesieur V (2008) Assainissement non collectif. Le moniteur, Paris

Calvet R (2003) Le Sol: propriétés et fonctions. Edition France Agricole, Paris

Childs S, Flint AL (1990) Physical properties of forest soils containing stone fragments. In: Weetman GF, Powers RF (eds) Sustained productivity of forest soils, University of British Columbia, Vancouver, pp 95-121

Cosby BJ, Homberger GM, Clapp RB, Ginn TR (1984) A statistical exploration of the relationships of soil moisture characteristics to the physical properties of soils. Water Resour Res 20:682-690

Cousin I, Nicoullaud B, Coutadeur C (2003) Influence of rock fragments on the water retention and water percolation in calcareous soil. Catena 53:97-114

Elrick DE, Reynolds WD, Tan KA (1989) Hydraulic conductivity measurements in the unsaturated zone using improved well analyses. GWMR 9:184-193

FAO (2006) Guidelines for soil description. FAO, Rome

Ferrer-Julià M, Estrela Monreal T, Sánchez Corral del Jiménez A, García Meléndez E (2004) Constructing a saturated hydraulic conductivity map of Spain using pedotransfer functions and spatialprediction. Geoderma 123:275-277

Fiès JC, Louvigny N (de), Chanzy A (2002) The role of stones in soil water retention. Eur J Soil Sci 53:95-104

Flury M, Flühler H, Jury WA, Leuenberger J (1994) Susceptibility of soils to preferential flow of water: a field study. Water Resour Res 30:1945-1954

Gee GW, Or D (2002) Particle-size analysis. In: Dane JH, Topp GC (eds) Methods of soil analysis part 4 physical methods. Soil Science Society of America, Inc., Madison, pp 255-293

Gómes JA, Giraldez JV, Fereres E (2001) Analysis of infiltration and runoff in an olive orchard under no-till. Soil Sci Soc Am J 65:291-299

Hénin S (1976) Cours de physique du sol, vol 1. Orstom Edition, Paris. Documentation technique, no 28

Lawes JB, Gilbert JH, Warington R (1982) On the amount and composition of the rain and drainage water collected at Rothamsted. W. Clowes and Sons Ltd., London
Lee DM, Reynolds DW, Elrick DE, Clothier BE (1985) A comparison of three methods for measuring saturated hydraulic conductivity. Can J Soil Sci 65:573-653

Liu W, Ou ZQ, Ying PF (2001) Soil macropores and their research methodology. Chin J Appl Ecol 12:465-468

Ma DH, Shao MG (2008) Simulating infiltration into stony soils with a dual-porosity model. Eur J Soil Sci 59:950-959

Ma D, Shao M, Zhang J, Wang Q (2010) Validation of an analytical method for determining soil hydraulic properties of stony soils using experimental data. Geoderma 159:262-269

Mohanty BP, Kanwar RS, Everts CJ (1994) Comparison of saturated hydraulic conductivity measurement methods for a glacial-till soil. Soil Sci Soc Am J 58:672-677

Nasri B, Fouché O, Saillé Ch, Forquet N, Seidl M, De Laure E (2012) Field monitoring and sampling of infiltrated soil water under onsite treatment systems, 4th International Congress of soil science societies (ECSSS), Bari-Italy

Poesen J, Lavee H (1994) Rock fragments in top soils: significance and processes. Catana 23:1-8

Reynolds WD, Bowman BT, Brunke RR, Drury CF, Tan CS (2000) Comparison of tension infiltrometer, pressure infiltrometer, and soil core estimates of saturated hydraulic conductivity. Soil Sci Soc Am J 64:478-484

Shi Z, Xu L, Wang Y, Yang X, Yang Z, Jia H, Guo W, Xiong Yu (2012) Effect of rock fragments on macropores and water effluent in a forest soil in the stony mountains of the Loess Plateau, China. Afr J Biotechnol 11:9350-9361

Soil Survey Staff (2010) Keys to soil taxonomy, 11th edn. USDA/ Natural Resource Conservation Service, Washington, DC

Spomer LA (1980) Prediction and control of porosity and water retention in sand soil mixtures for drained turf sites. Agron J 72:361-362

Stewart VI, Adams WA, Abdulla HH (1970) Quantitative pedological studies on soils derived from Silurian mudstones. II. The relationship between stone content and the apparent density of the fine earth. J Soil Sci 21:248-255

Tetegan M, Nicoullaud B, Baize D, Bouthier A, Cousin I (2011) The contribution of rock fragments to the available water content of stony soils: proposition of new pedotransfer functions. Geoderma 165:40-49

Torri D, Poesen J, Monica F, Busoni E (1994) Rock fragment content and fine soil bulk density. Catena 23:65-71

Towner GD (1988) The influence of sand- and silt-size particles on the cracking during drying of small clay dominated aggregates. J Soil Sci 39:347-356

Urbanek E, Shakesby RA (2009) Impact of stone content on water movement in water-repellent sand. Eur J Soil Sci 60:412-419

Verbist KMJ, Cornelis WM, Torfs S, Gabriels D (2012) Comparing methods to determine hydraulic conductivities on stony soils. Soil Sci Soc Am J 77:25-42

Weihermuller J, Siemens M, Deurer S, Knoblauch H, Rupp A, Göttlein K, Pütz T (2007) In situ soil water extraction: a review. J Environ Qual 36:1737-1748

Zhou BB, Shao MA, Shao HB (2009) Effects of rock fragments on water movement and solute transport in a Loess Plateau soil. CR Geosci 341:462-472 